\title{
COLOMBIAN FORMER REFUGEES AS VOLUNTEERS: REFRAMING PATRON-CLIENT RELATIONS AND EXCHANGE PRACTICES
}

\author{
Andrea Merino Ortiz ${ }^{1}$
}

\begin{abstract}
This article explores issues of social exchange amongst Colombian former refugees who do voluntary work for each other in Aotearoa, New Zealand. The complex dynamics enacted by those Colombians who consider themselves to be volunteers show how refugees reframe their cultural practices of exchange during settlement. They do so by negotiating the meaning and idioms of giving; in utilising the cultural narratives of resettlement - in this case, the language of voluntariado (volunteering) - former refugees deploy traditional structures of exchange, whilst simultaneously modifying their significance to fit their social milieu. This article uses two frameworks related to exchange practices: the Maussian notion of the gift and patron-client structures. It argues that Colombians' voluntariado is embedded in intricate systems of generosity and reciprocity that follow particular types of power imbalances and significantly resemble patron-client relations. Overall, Colombians' clientelistic notions of morality, loyalty, and friendship are fundamental to how they build sociality during settlement and are deeply important to how they understand themselves, their relationships, and their place in the world.
\end{abstract}

Keywords: refugees; resettlement; migration; sociality; social exchange

\section{INTRODUCTION}

In 2008, the New Zealand government began resettling Colombian refugees in Aotearoa, on average taking on 180 arrivals each year. Colombians are fleeing their country's civil war, which has persisted for more than five decades and shows no signs of abating. ${ }^{2}$ Since their arrival in New Zealand, Colombians have built intricate networks by doing 'voluntary work' for each other. In line with the phenomena explored in other articles in this issue, Colombians' settlement is ideologically and experientially grounded in how they build 
sociality by and through their distinctive notions of giving, loyalty, friendship, and helping.

In this article, I discuss issues of social exchange amongst Colombian former refugees who do voluntary work for each other. The complex dynamics enacted by those Colombians who consider themselves to be volunteers show how refugees reframe their cultural practices of exchange during settlement. I argue that they do so by negotiating the meaning and idioms of giving; in appropriating the cultural narratives of resettlement - in Colombians' case, the language of volunteering or voluntariado - former refugees reframe traditional structures of exchange, whilst simultaneously modifying the meaning and significance of these narratives to fit their social milieu. Voluntariado is a word Colombians often use to describe the kind of assistance they give each other in New Zealand. The semantic range of the Spanish term is specific to the context of resettlement, differing from English understandings of 'volunteering' because it encompasses informal and familial types of assistance. Rather than just saying that they 'help' their acquaintances, Colombians continually frame everyday acts of generosity through the idiom of voluntariado; this is a way of articulating acts of giving that they did not use prior to coming to New Zealand.

I witnessed the exchange systems underlying voluntariado over four months of fieldwork, from July to October 2017, when I attended over thirty Colombian events and conducted sixteen open-ended and semi-structured interviews with Colombian residents of Hamilton, Auckland, and Wellington. In addition, I conducted fourteen interviews with New Zealand volunteers and other host community members who worked closely with them. Of those Colombians who resettle in New Zealand, a significant number come from rural and lower-economic backgrounds and are of Afro-Colombian descent, historically those most severely affected by the civil war. Because the United Nations High Commissioner for Refugees (UNHCR) prioritises the resettlement of single mothers and children, women in their mid-forties and fifties constitute a high proportion of the Colombian former refugees who arrive through the Quota Programme. ${ }^{3}$ My participants' demographics aligned with these markers, as I interviewed eleven women (aged in their forties or early to mid-fifties, with only one in her mid-twenties) and five men (two of whom were in their late twenties and three in their forties or fifties). Of these, fourteen were Afro-Colombian or 'mixed race', and fifteen identified as having come from either rural settings or backgrounds of 'hard labour', having been farmers, factory workers, cleaners, or rural shopkeepers in Colombia. Three of my Colombian participants were single mothers, while the remaining thirteen lived in New Zealand with their partners or husbands, either having arrived together or the men having been 
resettled through the Family Reunification Programme. ${ }^{4}$ Colombians began arriving in New Zealand in 2008, after spending sometimes many years in Ecuador awaiting refuge.

My Colombian participants described - and showed through everyday actions - how they provided material support and favours to newly arrived Colombians during resettlement. These gestures often catalysed a multitude of effects, social repercussions, and different sets of obligations for those who received their help. All of which served to continue their exchange relationships and friendships well past the initial instance of generosity. I therefore use two frameworks related to exchange practices: the Maussian notion of the gift and patron-client structures. The latter belongs to a large body of anthropological work that originated in the study of Mediterranean and Latin American societies and theorised how power, generosity, gratitude, and loyalty can be enmeshed in interpersonal and social relationships (see Gouldner 1960; Graziano 1975; Li Causi 1975; Silverman 1965; Wolf 1966).

From the early stages of my fieldwork, it became apparent that my interlocutors were embedded in intricate systems of generosity and reciprocity that significantly resembled patron-client relations (Gilsenan 1977; Hicken 2011; Polanyi 1970 [2005]). Their relationships were highly emotional, layered, and committed, and, while Colombians often spoke of one another using words like comadre/compadre $e^{5}$ or voluntario (volunteer) rather than patrón (patron) or cliente (client), the power imbalances inherent in their exchanges clearly mirrored structures of patronage.

Former refugees' understanding of clientage also helped them negotiate the seeming tension between disinterested and self-interested giving. Their cultural perspective on giving allowed for openness around the intimacy of power, meaning the relationship between power and emotional closeness, such as feelings of love and affection, and how these two can often co-constitute one another. Colombians openly spoke about how 'disinterested giving' can involve a conscious or unconscious expectation that the benefactor will reciprocate. To give whilst expecting something in return did not seem to present a moral or ethical contradiction; their cultural perspective on social exchange held both beliefs simultaneously and seemingly unproblematically. While at times some people expressed veiled irritation or resentment towards the status differential between givers and receivers, Colombians ultimately conceptualised generosity as the utmost key value enacted by a 'good' person. Voluntarios who gave a lot, despite their sometimes mixed motivations and gains, were loved and considered to be the unifying glue between Colombians. 
Such is the case of Sofía, a Colombian woman who tries to visit most new intakes at the Mangere Refugee Resettlement Centre as a way of 'doing voluntary work' for 'her people. ${ }^{6}$ In the five years since her arrival in New Zealand, Sofía has invited them, and taken those who wished, to Catholic Mass in Spanish and provided them with a picnic lunch afterwards, showcasing her Colombian cooking. As I accompanied Sofía on one of her Mangere visits, I saw how her attention and efforts were positively received and openly reciprocated, providing her with long-time friends and loyal connections. Through her Mangere visits, Sofía established a large network of customers for her food business, which she had set up three years earlier in her home in Huntly, a town which is half-an-hour's drive away from Hamilton. She also became one of the most beloved members of her Colombian network.

Through examples like that of Sofía and other patrons I met, I present a social analysis that explores how Colombians' moralities and rationales of giving are reinterpreted, adapting the language of resettlement to fit new social settings. Former refugees' reformulation of volunteering meant that traditional forms of patronage were reinstated amongst resettled Colombians. Love, friendship, emotions, power, and the politics these entail were threaded through every aspect of their exchange practices and the social landscapes they created through voluntariado. I begin by discussing how social exchange was at the core of Colombian relationality, then I explore the ways patron-clientage was reinstated in their new social order; I conclude with a reflection on how notions of power and virtue were consolidated in their understanding of exchange.

\section{THEORIES OF SOCIAL EXCHANGE AND COLOMBIAN RELATIONALITY}

Anthropologists have studied forced migration for over seven decades and developed complex understandings of the experience and social ramifications of displacement (see Arensen 2012; Chatty 1977; Colson 1945; Das 1990; El-Shaarawi 2015; Kleinman, Das, and Lock 1997; Malkki 1995; Stein 1981). ${ }^{7}$ More closely related to this project, however, are those anthropologists who have used theories of social exchange to study relationships among former refugee cohorts (Danneskiold-Samsøe 2006, 2011; Lewis 2008; Richmond 1993; see Stewart 2014 for her analysis of social support amongst African refugees in New Zealand). This article is part of this body of work within the study of refugees and their social exchange practices post-resettlement, which belongs to the voluminous study of exchange at large and of patron-client literature in particular. With the case study of Colombian former refugees, I bring together the literatures of resettlement, refugees' social exchange, and patron-clientage, 
and hope to offer a new perspective on the remaking of traditional exchange practices through the process of resettlement.

For Marcel Mauss, the obligations of social exchange are the 'wide and enduring contract' of societies (1925 [1954],3). Exchange practices shape and consolidate social relations, and, as many others also suggest, the obligations around giving and receiving are arguably the very foundation of human society (e.g., Belshaw 1965; Kapferer 1976; Lévi-Strauss 1969; Sahlins 1965, 1972; Schneider 1974; Schrift 1997; Schwimmer 1973; Strathern 1971).

From the moment I entered the field, I saw evidence that overt forms of social exchange were at the centre of most Colombians' interactions. This was definitely the case for four exceptional participants in my research: forty-four-year-old Sofía; Roberto, a man in his late fifties who often helped Colombians navigate the complex tax and benefit system; and Luciana and Matías, a charismatic young couple who were introduced to me as two key people involved in the Colombian community'. They are all former refugees who conceive of themselves as volunteers to fellow Colombians. Since their arrival in New Zealand, they have risen to prominence in the Hamilton community. They are constantly involved in organising gatherings, helping others to overcome many of the challenges that resettlement presents, and providing material assistance to those who are struggling. Sofía's, Roberto's, Luciana's, and Matías's acts of generosity reflected what Mauss proposed: that to give is 'a moral transaction, bringing about and maintaining human, personal relationships between individuals and groups' (1925 [1954], ix). This is because 'to accept a gift is to express a desire to enter in partnership' (p.24). Maussian understandings of exchange help us understand how giving always carries three social obligations: the obligation to give, the obligation to receive, and - perhaps the most theorised - the obligation to return (see Schrift 1997).

This obligation was evident in the way Colombians spoke of their voluntariado and the kind of assistance they had received from each other. Colombians' 'obligation to give' was not only enacted in practice - in that people constantly helped each other cope with day-to-day events - but was also coded in the language they used to describe giving amongst them. Volunteering and helping were spoken of as a 'natural' or 'essential' part of 'Colombian culture'; people would often say that these acts came 'from the heart' and that they were 'innate' to most Colombians. Giving was a social expectation and a way of constituting moral, 'good' people; constantly giving and assisting others was thought to be a positive, quintessential trait in Colombian social standards. When speaking about Roberto, an older woman said: 
Colombians help each other, all the time - if we are able. And even if we do not have anything, we will try to give something to someone else. Whatever. We support each other and do favours, like driving each other to the supermarket, paying for petrol, those kinds of things. We like helping.

Many Colombians said things to me that showed they appreciated voluntarios' efforts in keeping the 'Colombian community together', and they were thought of as 'true examples of Colombian people'. Generosity was constantly elicited from former refugees as a key value. Giving, and giving abundantly, was a marker of a good person and part of the fabric with which people constructed social bonds and networks whilst resettling. For them, generosity is a crucial moral component of relationality.

While some scholars argue that gifting is a solely self-interested endeavour for example, Adam Smith (1812) proposes that humans utilise the physical and social world of gift-giving to fulfil their selfish desires - Mauss's framework is helpful in that it highlights how exchange is much more than the reallocation of resources or the deployment of symbolic capital. It is a way of creating meaning and social connections by and through the process of giving, receiving, and returning; exchange works through people's cultural understandings of morality and obligation to others, which in turn underlines that giving cannot be reduced solely to matters of self-interest. Gestures of generosity never sit outside social relations and obligations - they are an essential part of society's fabric and one of the main mediums we use to engage with, change, and live in our social worlds (Belshaw 1965; Sahlins 1965).

By using the medium of generosity and reciprocity, Colombians constituted their social worlds and arrangements. They formed networks that were made out of groups of people who kept to themselves and avoided socialising with other networks. What these groups had in common was a close, loyal friendship with one of the four voluntarios I met. Social groupings were made up of former refugees who either all knew a Colombian voluntario who helped them and had introduced them to each other, or had initially met because one person had helped the other. Members outside the Colombian community noticed this as well. When I asked a New Zealand community worker whether in his view the Colombian community was 'united,' he replied that 'the Colombian community is a little bit different' in that they did not all come under the leadership of one prominent member of the community. He elaborated: 
Almost like there will be a group of Colombian people and they all help each other, and they will have one person who will be the person who is not in charge, exactly, but the "go to person". And in that group of five or six families, there will be the person who makes sure they are all okay: see what they need or come to them if they need something. Small pockets within the community as a whole. And it is not so much related to where they live, but it is effectively made of smaller pockets. Those networks are definitely there; there is always someone who takes the responsibility for that group of people.

The popular notion of 'community' as a unified, homogeneous whole does not fit the reality of Colombian relationships. The stereotype of 'the community' is often used categorically to define ethnic minorities. In and of itself,'community' is 'one of the most vague and elusive concepts in social science' (Shore 1993, 98), because, as an idea, it has been socially constituted through essentialist rhetoric. People who interact with each other, belong to a social group, or live in close proximity do not necessarily 'perceive themselves' as a 'community' (Shore 1993, 98). The term problematically implies a sense of sameness or a unifying quality that binds a particular group. By contrast, Colombians' groups or networks were formed by and through acts of giving. Social relationships were not related to geographical position, as shown by Sofía, whose home in Huntly was a point of gathering for her friends who lived sometimes more than an hour away. Social relationships were also not related to the sheer commonality of being 'Colombian' or 'former refugees'. In reality, there was a sense of affiliation and loyalty to those voluntarios who constantly helped others and who 'looked after' a particular, siloed group. It is through these vertical arrangements, built upon a foundation of exchange, loyalty, and generosity, that relationality and sociality is established and cemented for Colombians.

The kinds of loyalties and allegiances Colombians make with people who give extensively create vertical structures of affiliation and, furthermore, competition between groups who are loyal to different voluntarios. Overall, the establishment of loyal and sometimes exclusive relationships was a key aspect of how Colombian networks expressed and negotiated their obligations vis-à-vis other relationships and groups of people.

Luciana and Matías, for example, had a solid group of friends who regularly visited them and who had become friends with each other through their introductions. I was told that, since the couple arrived in New Zealand seven years ago, people who needed help seemed to gravitate towards them, and Luciana and Matías would never turn them away. They were known for often having 
Colombians stay in their home for extended periods of time - whether because they were struggling financially, had a fight with their families, or just needed the emotional support - whilst 'expecting nothing in return'.

This kind of narrative was commonplace in voluntarios' networks, whereby the generosity of volunteers was constantly spoken of through notions of disinterestedness and altruism. After a few weeks of interacting with Colombian volunteers, however, I began to see how not 'expecting anything in return' did not mean that acts of reciprocity were not made towards - or even elicited by - those who helped.

\section{REFRAMING PATRON-CLIENT RELATIONS}

The relationships I witnessed, and at times was a part of, were established upon mutual benefit and power imbalances, yet they were also made of close, caring, and loving bonds. For example, the relationships Sofía built with newly resettled Colombians during the first weeks after their arrival at Mangere Centre often turned into long-term and deeply caring friendships. At the same time, her visits also helped her attract future customers for her food business.

The first time I met Sofía, I quickly gained a sense of the large number of people she was connected to and the kind of magnetic force she exercised. The moment I entered her kitchen on a Saturday morning, I realised that this was a central meeting place for many Colombians and other Latin Americans. There was at least five other people in the living room, waiting for their orders whilst talking, drinking coffee, and eating. Over the next few weeks, I visited and stayed in her kitchen for as many hours as I was able to. I cannot even recount the number of people I met in that time. Colombians and other Latin Americans came in and out, chatted, gossiped, and left as quickly as they arrived - carrying loads of food, polystyrene containers, or a full belly after sitting at the same table as me. Some, like me, stayed for longer and talked to Sofía, her husband, and others. Clearly, Sofía had continued helping others long after her Mangere trips, as many conversations revolved around the kinds of favours she was doing for others, from introducing people to potential employers to organising baby showers or looking after the many godchildren she and her husband had. One day I asked her how many godchildren they had, and she replied with a laugh, 'We already have so many! And we are about to baptise another one next month. I think we have more than ten'. In all her relationships, there was an implicit understanding that Sofía gave abundantly. Godparenthood, for instance, is a position imbued with obligations and moral responsibilities, and Sofía fulfilled these without missing an opportunity to be generous, always making sure she 
kept in touch with her godchildren's families and helping when needed or when she was asked.

Sofía and other voluntarios often helped through granting protection, favours, or material help or by mobilising their social capital, while the people they assisted returned friendship, love, loyalty, and clientletistic behaviours (such as supporting Sofía's food business or taking their car to Roberto's garage). My participants' relationships paralleled what anthropologists like Wolf (1966), Boissevain (1974), Campbell (1964), Foster (1963), Befu (1977), and J. C. Scott (1972) came to define as patron-client ties. Sydel Silverman's definition of the patron-client relation is considered by some to be the most helpful in clarifying the concept (Shore 2016). Silverman describes patron-client relations as informal contractual relationships between persons of unequal status and power, which impose reciprocal obligations of a different kind on each of the parties', in that 'as a minimum, what is owed is protection and favour on the one side and loyalty on the other' - this is why 'the relationship is on a personal, face-to-face basis, and it is a continuing one' $(1965,176$; see also Powell 1970, 412; Lemarchand and Legg 1972).

It is worth noting that the concept has been critiqued at length for being guilty of conceptual stretching (Kaufman 1974). It was said to be too expansive (Archer 1990,7), in that one could argue that most interpersonal relationships have an element of patronage and clientelism about them. This is because clientelism is founded in the inequalities of gift exchange itself. However, such critiques have been progressively resolved since the mid- to late 1970s, when Marxist interpretations of patron-client relations highlighted how such exchange practices are disguised forms of class power and hierarchy (Pitt-Rivers 1954, 154; Wolf 1966, 16). Patron-client relations perpetuate a differential power imbalance, placing the giver/patron on a higher status no matter how much the receiver attempts to repay them, and they are ongoing and unquantifiable - the things that are exchanged do not hold the same use value or symbolic capital (Sahlins 1965).

This description fitted most of the interactions between former refugees and Colombian voluntarios. Leidi, for instance, told me that she would always be grateful for the help Luciana and Matías offered when she arrived in New Zealand. According to her, they looked after her and her sister during a time when they were struggling financially. They invited the sisters over for most meals and offered emotional support and companionship, and it was through a connection of theirs that Leidi found a job as a nanny. Nowadays, she often visits and helps them out by running errands or assisting Luciana with the cooking. Leidi commented that continuing to help and visit them was her 'way of repay- 
ing them, and she continually praised them for the voluntariado they did for 'their people'. Although they had helped her over six years ago, she continued to repay them, showing no sign of stopping any time soon. Moreover, the couple had continued to offer help and favours throughout the years, cementing their exchange relationship and making it open-ended.

Similarly, my own relationship with Sofía became a clear example of a patronclient exchange. Before we met, we had briefly talked on the phone, and, in the course of a ten-minute call, she had swiftly agreed to help me in my research and to contact Colombian former refugees for interviewing, asked me to help her organise a Colombian gathering, and had started saying 'our research project'. One day, I asked Sofía whether she would be able to contact a few Hamilton residents and see if they would be interested in participating in the research. In passing, I once mentioned that if I were to go to Hamilton, I would be able to deliver her food to customers as a way of saying 'thank you' for her assistance. After passing on the phone numbers of the Hamilton residents, she asked me to deliver food parcels to three of her comadres, to drive her flatmate to church, and to bring dessert to the Colombian gathering she was organising.

And so it continued. Over several months our relationship followed the same pattern: whenever I went to Hamilton for research purposes, I delivered Sofía's food. The errands I ran for her often allowed me to meet Colombians and spot future participants. It was a mutually beneficial relationship, as my Hamilton trips saved Sofía time and petrol money. Our exchange mirrored 'generalised' and 'vertical' reciprocity (Sahlins 1965; see also Befu 1977), as Sofía was the primary giver in our interactions. I became a loyal friend, and I felt utterly indebted to her as she was the first person to help me contact participants for my research. To this day, I feel like there is no way of ever fully repaying her, as she made my research project possible.

Patron-client relations amongst my participants adapted to the context of resettlement in New Zealand. While one of the limitations of pre-1970s literature on patron-client exchanges was its focus on rural settings characterised by a sense of 'scarcity' (Gregory et al. 1975), another problematic perspective was that patron-clientelism was an ideal type, a 'gatekeeper' concept for defining Latin American and Mediterranean contexts (Gellner and Waterbury 1977; Gregory et al. 1975; Herzfeld 2015). However, from the 1970s onwards, anthropologists proposed that clientelism could manifest itself in other, less traditional contexts and relationships, such as bureaucratic organisations and institutions of the nation-state (Gellner and Waterbury 1977; Gilsenan 1977; Gupta 1995; Schneider and Schneider 2001). 
Since the 1970 and more recently, anthropologists have returned to the concept to show how such relationships can have other articulations and manifestations in globalised settings. The concept has been resurrected from its pre-197os existence, re-contextualised, and re-theorised in nuanced ways (Beer and Gardner 2015; Greenfield 2014; Hicken 2011; Molina et al. 2017; Shore 2016). ${ }^{8}$ This trend was also seen amongst political scientists (Eisenstadt and Roniger 1980; Gordin 2002; Gudeman and Rivera 1990), who argued that patron-client relationships had adapted to contexts intensified by globalisation and social change, shifting political arrangements, and macro-economic forces.

Such reformulations of patronage were evident amongst Colombians, as former refugees recreated traditional structures of patronage and adapted them to contemporary logics of resettlement and humanitarianism. Archer's study of clientelism in Colombia shows that patron-client relations are 'prevalent throughout large sectors of the population, [covering] virtually every facet of [...] social life' $(1990,17)$; they are not just avenues for people to find material and symbolic advancement. Archer $(1990,17)$ notes that everyday Colombian patron-client relations become durable in instances where high levels of affection and mutual respect exist amongst participants. From the perspective of Colombians, mutual respect is a key value for strengthening a relationship between patrons and clients. It is also a moral compass which allows people to distinguish between those who are generous and those who use their position of power to exploit and manipulate people in weaker positions. In Colombia, clientelistic notions of generosity are more than elements of political and material processes: they are everyday practices of relationality. They rest on morals such as respect, obligation, and values that are thought to constitute a good person.

As Roniger suggests, patronage and clientelism have endured changing contexts, morphing in accordance with post-modern logics and globalisation $(2012,25)$, and are seen to be 'provid[ing] access for migrant populations' to resources, social mobility, and social relations $(2012,28)$. In this way, Colombians use voluntariado, as an idiom borrowed from the language of resettlement and forced migration, to reframe their patron-client exchanges in the context of New Zealand. Transferring everyday, moral, and relational practices of exchange from Colombia necessitated a rearrangement of language. Voluntariado's semantic shift made it an open signifier, through which Colombian traditional understandings of generosity were communicated and became quotidian in the context of resettlement. Former refugees thus deployed their understandings in new circumstances through a process of reinterpretation. 
Roberto was well known in a network of Colombians as the 'go-to guy' for completing tax and Work and Income forms. Many struggled with the complex benefit system and navigating the structures for accessing welfare. Roberto arrived in New Zealand nine years ago and, unlike most other Colombians who resettle in their adult years, had gained a good command of the English language. According to him, he had 'unofficially' become involved with a few resettlement organisations and had gained much experience in guiding Colombians through the difficult pathways of the Inland Revenue Department (IRD), Work and Income New Zealand, ${ }^{9}$ and StudyLink, a private company hired by the government to provide student loans.

Roberto's friends often contacted him for such help. He called these acts of assistance voluntariado. When I asked him how he differentiated between voluntariado and the help he would offer friends in general, he responded that voluntariado, for him, meant helping with challenges related to resettlement. He said that the kind of volunteering he did is something that even [other organisations'] volunteers cannot do themselves', because he knew so much about the benefit and tax system. He explained that, many a time, his Colombian acquaintances would recommend his services to strangers who were encountering difficulties and who would contact him asking for his help. Roberto said that word got around of the kind of help he provided, and he was later contacted by the Red Cross, the 'primary provider of community refugee resettlement programmes in New Zealand' (New Zealand Red Cross n.d.). The Red Cross asked him whether they could redirect some of their clients to Roberto, and he 'gladly accepted.' He said, 'Then I was in very good terms with those organisations and they gave me very good feedback and recommendations when I started applying for jobs'.

Roberto can be thought of as a perfect example of a 'middleman', a position that many patrons take on. The notion of 'cultural brokers' dates back to foundational writings on social exchange (Mauss 1925 [1954]) but was developed in the literature on clientelism around the 1960s (Li Causi 1975; Pitt-Rivers 1954; Silverman 1965; Wolf 1966). Patrons were said to be key mediators in rural forms of part-whole relationships within complex societies; they acted as brokers between government agents and peasants, introducing peasants to the people they needed to know if they visited the city. They were the social link between rural, marginal communities and outside institutions beyond village arrangements. Essentially, this mediatory role enabled patrons to serve as gatekeepers between local infrastructure and nation superstructure (Kenny 
1960), agents who solidified exchanges between economic and political groups at the national level and individuals or groups within local contexts. With his voluntariado, Roberto became the broker between unassimilated Colombians and organisations that coordinated national structures of welfare.

In broker-type exchanges, patrons hold considerable social capital and power because they know the rules of exchange for interacting with both parties and often have an advantage in relation to their clients. Roberto had the social capital (knowledge) that his friends or clients lacked and, in mediating between them and social institutions, asserted a status of 'protector' and 'legal expert' within the Colombian network he associated with. He was well respected and loved by those he helped, and people often expressed their gratitude for his 'knowledgeable' assistance. They frequently visited him and his family and, most importantly, publicly praised him for being one of the 'smartest' and strongest 'rocks' in the Colombian community.

Roberto's generosity was reciprocated with clientelistic expressions of loyalty and support. Clara, one of the people he had helped, told me that in 2016, Roberto's 'friends helped him' through a time of illness, when he became housebound and was unable to work for three months. Throughout this 'challenging time', many families visited him and his wife, made food for them, and helped with the garden - saying things like they 'would not leave him alone through this' and 'would always be by his side'. I was surprised to hear that, even when he was unwell, Roberto continued to receive many calls from strangers or people he knew and gave 'his expert advice' to those who sought his assistance.

At the same time, his voluntariado advanced his position with the organisations he worked with. Although he said that their partnership was 'unofficial', in that there was 'nothing on paper', Roberto was well known within Red Cross circles. At times, whilst interviewing other Colombians and conversing with agency workers, I would realise that they were talking about Roberto from their account of the kinds of assistance he provided. By building his reputation with these organisations, he was able to receive good recommendations from them and eventually found a stable job. Moreover, crucially in cultural broker relationships, the broker has advantages that are relevant for government institutions; Roberto's 'legal expertise' saved agency workers the task of guiding Colombians through complicated forms and bureaucracies - at no expense and with no need for 'official' recognition.

Through my conversations with others, however, I noticed that Roberto's voluntariado extended well beyond his 'legal advice' regarding resettlement. He 
was known amongst his friends as a generous man who would offer everyday help, such as giving people a lift to the supermarket or organising social events for Colombian youths. Although Roberto said his voluntariado was limited to assistance with bureaucratic elements of resettlement, I sensed that, from others' perspective, his volunteering may not have been so clearly defined. Because Roberto took on the role of protector- and helper-at-large, his voluntariado blurred in and out of his conscious wish to help strictly with matters of resettlement. His attempt to fulfil a patron's obligation to give abundantly caused his voluntariado to merge ambiguously with the day-to-day assistance he also provided.

Throughout these mechanisms of reformulating patron-client exchange, the idioms of volunteering and generosity were continually reinterpreted through notions of disinterested giving and self-gain. On the one hand, Roberto's benefiting from his voluntariado did not seem to change people's opinions of his work as 'disinterested', 'generous', and 'good'. By and large, when others recounted how he had gained so much from 'his acts of help', many reiterated that such effects were 'a natural outcome' of generosity. When I asked if they thought the outcome changed the act itself, they responded with a sharp 'no', stating that it was a 'good thing' that Roberto was able to reap the benefits of his generosity. Although voluntariado carried pertinent sets of obligations, power imbalances and elicited loyalty, former refugees did not negate the notion of disinterested generosity in their daily lives and relations with voluntarios. The way in which they articulated their relationships relied heavily on the lived experience of generosity, the emotional qualities of giving, and the bonds that were constituted.

On the other hand, in more private settings, a couple of people alluded to Roberto's interest in money and focus on working hard and acquiring possessions. One day as I had coffee with a family at their house, the grandfather said, 'That Roberto is very interested in money, isn't he? He and his wife are always after money'. When talking to another woman over lunch about how Roberto was famous for organising social gatherings, she mentioned that some people were not very outgoing and would rather keep to themselves, adding, with a nervous laugh, 'But they would cooperate if Roberto encouraged them to cooperate - but he is an exceptional person out there, really'.

These indirect remarks were implicitly coded with what I interpreted as resentment. According to Maussian analyses of exchange, the giver holds more social status and power - be it cultural capital, symbolic presence, or political and economic influence (1925 [1954], 31). In Mauss's explanation of honour and credit, the process of giving and returning a gift follows a pendular fluctuation 
of power, whereby returning gifts is a way that the debtor attempts to become the creditor (1925 [1954], 31). The power imbalance in patronage systems is often lived through ambivalent feelings of gratitude and resentment (Gouldner 1960), because the debtor can hardly ever become the creditor - unless it be with others who are not their patrons. In the interactions between Roberto and his friends/clients, the power dynamics left some people with a covert, yet subtly obvious, deficit. Not only did Roberto have the material, social, or symbolic capital they needed, he also had virtue. He was a 'good person', he was a 'generous man', yet the ways in which they could repay his gifts and acts of generosity never amounted to equal symbolic and material value and, therefore, never fully settled their social debt.

I interpreted resentment to be at play another day, when Luciana and I visited one of the couples who had made her godmother to their children. While chatting casually, Luciana asked Rosita, the family's thirteen-year-old daughter, if she was excited about her upcoming confirmation. Rosita smiled and replied with a shy 'yes', although, she muttered, she had still not found 'the right dress' for the occasion. Without a moment of hesitation, Luciana said, 'I can make your dress - I am an experienced seamstress! Just give me your measurements and tell me what style you want. While Rosita's mother was beaming with a big smile, saying many times 'thank you' and 'God bless you', I could not help noticing Rosita's father as he sat silently in his chair. Solemnly looking at the ground, in not much more than a faint whisper, he echoed, 'Yes, may God bless you'. I knew that his family had been friends with Luciana and Matías since they arrived in Hamilton and suspected that the more generous Luciana was, the less able they were to fully repay her, let alone become creditors in their relationship.

While I did not ask Rosita's father whether he felt resentful, as this would have been an inappropriate question in such a setting, I read his reaction as resentment due to my knowledge of patron-clientage and the framework's emphasis on power imbalance and the client's sense of never-ending indebtedness. However, other feelings could have been at play, such as shame, as the father's role as breadwinner was potentially challenged when he was put in the role of the recipient of patronage. In addition, receiving help might have unbalanced his sense of masculinity and therefore resulted in a mix of emotions that could have been more than resentment. All in all, however, witnessing this exchange made it clear to me that being placed in an unequal power dynamic, whereby exchange relations follow those of a patron-client framework, can catalyse complex and dissonant sets of emotions in those who are receiving a patron's help and material gifts. 
The constant exchange of favours sustained a fixedness of status, as Sofía, Roberto, Luciana, and Matías typically were able to give more and had ongoing authority within their Colombian networks. Nonetheless, others told me that the four did voluntariado because they had a great 'love for their people.' I noticed in their friends and clients a clear oscillation between affectionate gratitude and implicit resentment. I was sometimes surprised at how Colombians were able to express both sentiments in one set of narration. Although resentment was apparent only a handful of times during my research, I was able to see how feelings of gratitude and resentment were often consolidated in their experiences and narrations of exchange. But overall in their accounts, people would always return to articulations of gratitude and the affection they felt for voluntarios - gratitude was essential for how they understood and expressed their experiences.

The more I encountered these narratives oscillating between gratitude and resentment and between notions of disinterested and self-interested giving, the more I realised that the meaning and value of exchange were constantly negotiated and reinterpreted. The more Colombians deployed the language of voluntariado to constitute patronage systems within their networks, the more the term and practice of volunteering came to acquire complex and intricate moral implications, obligations, and expectations. However, people generally navigated these complexities through their expressions of gratitude and their understandings of disinterested giving; these were the overarching narratives they used to arrange and talk about their lives and relationships.

I was able to experience this oscillation - between gratitude, love, and resentment - through my own relationship with Sofía. Our interactions had become clear examples of patron-client exchanges, me being the client, due to my lack of resources and contacts, and Sofía the patrona, who held the nonexchangeable 'goods' I needed. Her social status and capacity to give these resources were far greater than the use she could have of my services as a food deliverer. In our exchanges, she always gave more. As Mauss and Wolf propose, she held more power and more influence over my actions. Over time, I never felt I could fully pay off my debt to her, and this at times caused me to feel slightly resentful, as I often felt that what I did was 'never enough'. Nonetheless, I simultaneously felt incredibly grateful. Moreover, an equally important facet of our relationship was the personal and affectionate friendship we shared.

Although many scholars have analysed the quality of 'affection' and 'closeness' in patron-client structures through the rubric of ideology - arguing that affection 
obscures the maintenance of class relations and inequality between patrons and clients - I suggest that to think solely of emotions in that way limits our view of Colombian sociality and exchange. Ultimately, Sofía and I became close friends and, despite the undeniable tensions within our relationship, cared for one another. Similarly, friendship and emotional closeness were, by and large, the experiential outcomes of Luciana's, Matías's, and Roberto's voluntariado.

One day, following the death of my father in Mexico, I arrived at Sofía's house to pick up a bunch of green bananas I had ordered on behalf of my mother, who was also Sofía's customer by this point. Though I attempted to conceal my emotional state, Sofía asked me, 'Oh, Andrea, what's wrong? Is it the death of your father that is bothering you? You must be so sad'. I replied that I was also concerned about my extended family, who were proving to be very difficult in the legal process of my father's will, particularly my father's sister, who seemed angry that my father had made me his sole benefactor. I was conflicted about whether or not I should go to Mexico to resolve everything myself.

Sofía suddenly became extremely concerned and said she was worried about my safety if I were to go to Mexico:

I have seen so many people get killed by their own relatives when money is involved. So many brothers and sisters murder each other for a piece of land, for an inheritance. My own family members have threatened to kill each other over those kinds of disputes. Please Andrea, be careful.

She asked me if I could be represented by someone else. I replied that my maternal aunt had offered to do this for me. Sofía insisted that I not go to Mexico and continued to relate to me instances she knew where people had been seriously injured or killed by 'their own blood. This conversation lasted about two hours. By the end of it she was clearly emotionally distressed.

Here was my patron giving me unsolicited advice on how to preserve my own safety. This was not a favour that I felt needed repayment. In her earnest exhortations I heard something else: affection and caring concern. I could see that Sofía was coming from a place of love. Similarly, during my interactions with other Colombian voluntarios, I was intrigued to find how often morality, emotion, and power manifested simultaneously. These elements were not independent or separate from their relationships; they were often enmeshed and deeply related. 
In the early literature, many Marxist anthropologists overlooked some of the moral and affective dimensions of the relationships in patron-client exchanges. They primarily framed these with the paradigm of ideology and largely failed to show the complexity of the emotional and personal connections that patrons and clients may come to have. They proposed that the language of friendship and emotional closeness was merely a way of hiding the inequality in relationships (Campbell 1964; Davis 1977). The patron-client literature evokes the political force of emotion (Ahmed 2004; Lutz and Abu-Lughod 1990), but, in my experiences with Sofía and as I came to see with many other Colombian volunteers, emotion was a considerable factor in the shaping of relationships beyond class struggle and inequality.

Similarly, Roberto told me about one of his Colombian acquaintances, Pablo, a Colombian former refugee who had arrived in New Zealand two years earlier and who had recently been diagnosed with terminal cancer. Having helped him apply for a StudyLink loan - which he would use to study for a hospitality diploma - Roberto heard the diagnosis and became distraught, saying repeatedly that he could not believe this could happen to someone 'so young, only twenty-eight years old'. Roberto and his wife decided to take Pablo some food:

We went to visit him, and, as we entered his tiny apartment, I turned to my wife and said, "Oh my God, he has no chairs, no table, no couch - just a mattress on the floor". I could not believe the conditions he was living in. It broke my heart. I could not bear it. So we gave him our couch and bought him a table and chairs at a second-hand shop.

During the last two months of Pablo's life, Roberto and his wife stayed by his side, providing company, emotional support, and material help. One morning, I visited Roberto and he spent around two hours talking about how Pablo was not doing well at the hospital and how terribly sad he felt. His eyes filled with tears as he related to me how Pablo was dehydrated and delirious. Roberto was beside himself, expressing his frustration at his inability to help more. That same evening, Roberto texted me that Pablo had just passed away and that his service would be held two days later.

Despite his high status and capacity to 'encourage' Colombians to help with whatever he needed, Roberto visibly cared for those he helped. Although Pablo was not Roberto's client, since he was not able to return his assistance, Roberto's reaction reveals how - despite the inequality in his relationships - he also helped out of concern and affection. 
Overall, the idiom of voluntariado was used to reframe traditional forms of exchange practices amongst Colombian former refugees. Patron-client ties were at the heart of how Colombian voluntarios interacted with those they helped and served as the social structures through which they constituted sociality and relationality. Within these exchanges, economic, political, affective, and emotional forces and understandings of love, friendship, and loyalty were the primary principles underpinning their social relationships. However, despite tensions within their narratives of generosity, self-gain, and gratitude, the notion of disinterested generosity was deeply important to how Colombians understood themselves, their relationships, and their place in the world.

The close interplay between love, affection, and power does not negate generosity in practice and experience. Allowing Colombians to articulate their relationships with others through their cultural understandings of exchange meant not overriding their narratives with readings of power and ideology. Power differentials were indeed at play in their interactions, and yet, in an emotional register, Colombians also experienced and expressed their relationships through notions of generosity, love, gratitude, and disinterestedness. While emotional closeness has frequently been categorised in patron-client literature as a mechanism of control, on an experiential register, it transcended such categorisation because it was essential to how Colombians constructed their relationships and feelings of connection in the process of resettlement.

NOTES

1 Andrea Merino Ortiz completed her Master of Arts in Social Anthropology at The University of Auckland. Her research explored the relationships between Colombian former refugees and volunteers in Auckland, Hamilton and Wellington, New Zealand. Drawing on theories of social exchange, her thesis proposed that their interactions were often framed around synergetic, and sometimes contending, notions of gifting, reciprocity and obligation.

Email: amero52@aucklanduni.ac.nz

2 Unlike most conflicts, which on average last seven to fifteen years (Collier, Hoeffler and Soderbom 2004), Colombia's war continually draws in multiple armed groups with constantly changing faces, allegiances, political agendas, and economic aims. Although initially the war was sparked by the Revolutionary Armed Forces of Colombia - a left-wing rebel group commonly known as the FARC - in the last twenty years it has metamorphosed into an internal war of organised 
crime and drug-trafficking gangs. Colombian civilians have been displaced both internally and internationally, and they currently comprise one of the largest refugee and asylum-seeking populations in the world (UNHCR 2017).

3 Following the United Nations' 1951 Refugee Convention, New Zealand began to offer residency for displaced people. This is currently stipulated in the Sixth Schedule of the Immigration Act 1987 (No. 74), which formalised an annual resettlement quota of 800 places - although this number was increased to 1,500 in 2019 - through the Refugee Quota Programme.

4 This is a category offered by Immigration New Zealand to 'facilitate the successful resettlement of mandated refugee residents in New Zealand by providing them with an opportunity to sponsor immediate family members' (Immigration New Zealand 2012).

5 Spanish, i.e., the parent of your godchild or your child's godparent. Colombians use these words to refer to friends who are godparents to their children or to whose children they are godparents. These terms can also be used to describe a close friendship, regardless of whether there is a connection through godparenthood.

6 Like other former refugees who enter New Zealand, Colombians spend their first six weeks at the Mangere Refugee Resettlement Centre, where they go through the Educational Resettlement Programme. This is supposed to help them prepare for resettlement; services provided include English-language classes, an outline of New Zealand's cultural landscape, health screening, and mental health support. They are then resettled in different main cities around New Zealand.

7 More specifically, the literature on refugee resettlement has addressed notions of identity (Baškauskas 1977; Gabiam 2006; Malkki 1995; Mortland 1987; Muecke 1987; Weissköppel 2013); refugees' ability to achieve economic and political selfsufficiency (Ager and Strang 2008; Duchon 1997; Finnan 1982; Glazebrook 2004; Kenny and Lockwood-Kenny 2011; Warriner 2007); social and collective suffering (Adam 2008; Fadlalla 2009; Gozdziak 2002; Malkki 1995); trauma and the pathologising of refugees (Fadlalla 2009; Fassin 2008); the effects of humanitarian intervention (Feldman 2007; Harrell-Bond and Voutira 1992); development and policy-making (Gabiam 2006; Haines 1982; Howell 1982; Koenig 1997; Patnaik 1989; Simich 2003); and the discursive or epistemic construction of 'the refugee' (Adam 2008; Giroux 2006; Jing 1999; Malkki 1992, 1995; McGranahan 2016). Much of the scholarship between the late 1980 os and early 2000 s has followed political economy, phenomenological, or social suffering approaches to refugees' 
experiences and memories and the structural violence they face (Adam 2008; Desjarlais and Kleinman 1994; Gozdziak 2002).

8 The later anthropology of patron-client relations has been used elsewhere, but the Mediterranean and Latin American literature was more relevant for this project. Moreover, I have found that the subject of patron-client relations within the Colombian context has been researched within the field of political studies (see Archer 1990; Eisenstadt and Roniger 1980; Gordin 2002; Hall 1974; Powell 1970; Roniger 2012), which provides insightful analysis for anthropologists.

9 Part of the Ministry of Business, Innovation and Employment that supports people with a weekly benefit while they are looking for a job.

\section{REFERENCES}

Adam, Jeroen. 2008. 'Forced Migration, Adat, and a Purified Present in Ambon, Indonesia. Ethnology 47 (4):227-238.

Ager, Alastair, and Alison Strang. 2008. 'Understanding Integration: A Conceptual Framework'. Journal of Refugee Studies 21 (2):166-191.

Ahmed, Sara. 2004. The Cultural Politics of Emotion. Edinburgh: Edinburgh University Press.

Archer, Ronald P. 1990. 'The Transition from Traditional to Broker Clientelism in Colombia: Political Stability and Social Unrest'. Working Paper 140. Helen Kellogg Institute for International Studies, University of Notre Dame Press, Notre Dame, IN.

Arensen, Lisa J. 2012. 'Displacement, Diminishment, and Ongoing Presence: The State of Local Cosmologies in Northwest Cambodia in the Aftermath of War'. Asian Ethnology 71(2):159-178.

Baškauskas, Liucija. 1977. 'Multiple Identities: Adjusted Lithuanian Refugees in Los Angeles'. Urban Anthropology 6 (2):141-154.

Beer, Bettina, and Don Gardner. 2015. 'Friendship, Anthropology of'. In International Encyclopaedia of the Social and Behavioural Sciences. 2nd ed. Vol. 9, edited by J. D. Wright, 425-431. Oxford: Elsevier. 
Befu, Harumi. 1977. 'Social Exchange'. Annual Review of Anthropology 6:255-281.

Belshaw, Cyril S. 1965. Traditional Exchange and Modern Markets. Englewood Cliffs, NJ: Prentice-Hall.

Boissevain, Jeremy. 1974. Friends of Friends: Networks, Manipulators and Coalitions. Oxford: Blackwell.

Campbell, John Kennedy. 1964. Honour, Family and Patronage: A Study of Institutions and Moral Values in a Greek Mountain Community. Oxford: Clarendon Press.

Chatty, Dawn. 1977. 'Leaders, Land, and Limousines: Emir Versus Sheikh. Ethnology $16(4): 385-397$.

Collier, Paul, Anke Hoeffler, and Mans Soderbom. 2004. 'On the Duration of Civil War'. Journal of Peace Research 41 (3):253-273.

Colson, Elizabeth. 1945. 'The Makah: A Study of Assimilation' PhD dissertation, Radcliffe College, Cambridge, MA.

Danneskiold-Samsøe, Sofie. 2006. 'The Moral Economy of Suffering: Social Exchange Among Iraqi Refugees in the Danish Welfare State' PhD thesis, University of Copenhagen.

Danneskiold-Samsøe, Sofie. 2011. 'Suffering for Benefits? Integration and Social Exchange Between Iraqi Refugees and Danish Welfare Institutions'. In The Question of Integration: Immigration, Exclusion and the Danish Welfare State, edited by Karen Fog Olwig and Karsten Paerregaard, 187-206. Newcastle upon Tyne, UK: Cambridge Scholars Publishing.

Das, Veena. 1990. 'Our Work to Cry: Your Work to Listen'. In Mirrors of Violence: Communities, Riots and Survivors in South Asia, edited by Veena Das, 345-398. Delhi: Oxford University Press.

Davis, John. 1977. People of the Mediterranean: An Essay in Comparative Social Anthropology. London: Routledge \& Kegan Paul.

Desjarlais, Robert, and Arthur Kleinman. 1994. 'Violence and Demoralization in the New World Disorder'. Anthropology Today 10 (5): 9-12. 
Duchon, D. A. 1997. 'Home Is Where You Make It: Hmong Refugees in Georgia'. Urban Anthropology and Studies of Cultural Systems and World Economic Development 26 (1):71-92.

Eisenstadt, S. N., and Louis Roniger. 1980. 'Patron-Client Relations as a Model of Structuring Social Exchange'. Comparative Studies in Society and History $22(1): 42-77$.

El-Shaarawi, Nadia. 2015. 'Living an Uncertain Future: Temporality, Uncertainty, and Well-Being among Iraqi Refugees in Egypt'. Social Analysis 59 (1):38-56.

Fadlalla, Amal Hassan. 2009. 'Contested Borders of (In)humanity: Sudanese Refugees and the Mediation of Suffering and Subaltern Visibilities'. Urban Anthropology and Studies of Cultural Systems and World Economic Development 38 (1):79-120.

Fassin, Didier. 2008. 'The Humanitarian Politics of Testimony: Subjectification through Trauma in the Israeli-Palestinian Conflict'. Cultural Anthropology $23(3): 531-558$.

Feldman, Ilana. 2007. 'Difficult Distinctions: Refugee Law, Humanitarian Practice, and Political Identification in Gaza. Cultural Anthropology 22 (1):129-169.

Finnan, Christine R. 1982. 'Community Influences on the Occupational Adaptation of Vietnamese Refugees'. Anthropological Quarterly 55 (3):161-169.

Foster, George M. 1963. 'The Dyadic Contract in Tzintzuntzan, II: Patron-Client Relationship'. American Anthropologist 65 (6):1280-1294.

Gabiam, Nell. 2006. 'Negotiating Rights: Palestinian Refugees and the Protection Gap'. Anthropological Quarterly 79 (4):717-730.

Gellner, Ernest, and John Waterbury, eds. 1977. Patrons and Clients in Mediterranean Societies. London: Duckworth.

Gilsenan, Michael. 1977. 'Against Patron-Client Relations'. In Patrons and Clients in Mediterranean Societies, edited by Ernest Gellner and John Waterbury, 167-183. London: Duckworth.

Giroux, Henry A. 2006. 'Reading Hurricane Katrina: Race, Class, and the Biopolitics of Disposability'. College Literature 33 (3):171-196. 
Glazebrook, Diana. 2004. 'Becoming Mobile after Detention'. Social Analysis $48(3): 40-58$.

Gordin, Jorge P. 2002. 'The Political and Partisan Determinants of Patronage in Latin America 1960-1994: A Comparative Perspective'. European Journal of Political Research 41(4):513-549.

Gouldner, Alvin W. 1960. 'The Norm of Reciprocity: A Preliminary Statement'. American Sociological Review 25 (2):161-178.

Goździak, Elżbieta M. 2002. 'Spiritual Emergency Room: The Role of Spirituality and Religion in the Resettlement of Kosovar Albanians'. Journal of Refugee Studies 15 (2):136-152.

Graziano, Luigi. 1975. 'A Conceptual Framework for the Study of Clientelism'. Occasional Paper No. 2, Western Societies Program, Center for International Studies, Cornell University, Ithaca, NY.

Greenfield, Sidney M. 2014. 'The Flow of Goods and Service in Hierarchically Ordered Rural Societies: Patronage, Clientage, and the Livro da Virtuosa Bemfeitoria of the Infante Dom Pedro of Portugal'. In Production, Consumption, Business and the Economy: Structural Ideals and Moral Realities, edited by Donald C. Wood, 375-407. Bingley, UK: Emerald Group Publishing Limited.

Gregory, James R., Peter J. Bertocci, H.J.M. Claessen, Matthew Cooper, Peter Coy, Alain Y. Dessaint, Ronald J. Duncan, George M. Foster, Charles A. Lave, Grant McCall, Thomas J. Maloney, Manning Nash, Claude Robineau, Richard F. Salisbury, H.K. Schneider and Sharon W. Tiffany. 1975. 'Image of Limited Good, or Expectation of Reciprocity? [and Comments and Reply]'. Current Anthropology 16 (1):73-92.

Gudeman, Stephen, and Alberto Rivera. 1990. Conversations in Colombia: The Domestic Economy in Life and Text. Cambridge: Cambridge University Press.

Gupta, Akhil. 1995. 'Blurred Boundaries: The Discourse of Corruption, the Culture of Politics, and the Imagined State'. American Ethnologist 22 (2):375-402.

Haines, David W. 1982. 'Southeast Asian Refugees in the United States: The Interaction of Kinship and Public Policy'. Anthropological Quarterly 55 (3):170-181.

Hall, Anthony. 1974. 'Patron-Client Relations'. Journal of Peasant Studies 1(4):506-509. 
Harrell-Bond, Barbara E., and Eftihia Voutira. 1992. 'Anthropology and the Study of Refugees'. Anthropology Today 8 (4):6-10.

Herzfeld, Michael. 2015. 'The Village in the World and the World in the Village: Reflections on Ethnographic Epistemology'. Critique of Anthropology $35(3): 338-343$.

Hicken, Allen. 2011. 'Clientelism'. Annual Review of Political Science 14:289-310.

Howell, David R. 1982. 'Refugee Resettlement and Public Policy: A Role for Anthropology'. Anthropological Quarterly 55 (3):119-125.

Immigration New Zealand. 2012. 'Refugee Quota Family Reunification Category'. Accessed 18 June 2018 from http//www.immigration.govt.nz/opsmanual/4365o.htm

Jing, Jun. 1999. 'Villages Dammed, Villages Repossessed: A Memorial Movement in Northwest China'. American Ethnologist 26 (2):324-343.

Kapferer, Bruce. 1976. 'Introduction: Transactional Models Reconsidered'. In Transaction and Meaning: Directions in the Anthropology of Exchange and Symbolic Behavior, edited by Bruce Kapferer, 1-22. Philadelphia: Institute for the Study of Human Issues.

Kaufman, Robert R. 1974. 'The Patron-Client Concept and Macro-Politics: Prospects and Problems'. Comparative Studies in Society and History 16 (3):284308 .

Kenny, Michael. 1960. 'Patterns of Patronage in Spain'. Anthropological Quarterly $33(1): 14-23$.

Kenny, Paul, and Kate Lockwood-Kenny. 2011. 'A Mixed Blessing: Karen Resettlement to the United States'. Journal of Refugee Studies 24 (2):217-238.

Kleinman, Arthur, Veena Das, and Margaret Lock, eds. 1997. Social Suffering. Berkeley: University of California Press.

Koenig, Dolores. 1997. 'Competition among Malian Elites in the Manantali Resettlement Project: The Impacts on Local Development'. Urban Anthropology and Studies of Cultural Systems and World Economic Development $26(3 / 4): 369-411$. 
Lemarchand, Rene, and Keith Legg. 1972. 'Political Clientelism and Development: A Preliminary Analysis'. Comparative Politics 4(2):149-178.

Lévi-Strauss, Claude. 1969. The Elementary Structures of Kinship. Boston: Beacon Press.

Lewis, Denise C. 2008. 'Types, Meanings and Ambivalence in Intergenerational Exchanges Among Cambodian Refugee Families in the United States'. Ageing and Society 28 (5): 693-715.

Li Causi, Luciano. 1975. 'Anthropology and Ideology: The Case of "Patronage" in Mediterranean Societies'. Critique of Anthropology 2 (4-5):90-109.

Lutz, Catherine A., and Abu-Lughod, Lila, eds. 1990. Language and the Politics of Emotion. Paris: Éditions de la Maison des Sciences de l'Homme.

Malkki, Liisa. 1992. 'National Geographic: The Rooting of Peoples and the Territorialization of National Identity among Scholars and Refugees. Cultural Anthropology 7 (1):24-44.

Malkki, Liisa H. 1995. Purity and Exile: Violence, Memory, and National Cosmology among Hutu Refugees in Tanzania. Chicago: University of Chicago Press.

Mauss, Marcel. 1925 [1954]. The Gift: Forms and Functions of Exchange in Archaic Societies. Translated by Ian Cunnison. London: Martino Fine Books.

McGranahan, Carole. 2016. 'Refusal and the Gift of Citizenship'. Cultural Anthropology $31(3): 334-341$.

Molina, José Luis, Miranda J. Lubbers, Hugo Valenzuela-García, and Silvia GómezMestres. 2017. 'Cooperation and Competition in Social Anthropology'. Anthropology Today 33 (1):11-14.

Mortland, Carol A. 1987. 'Transforming Refugees in Refugee Camps'. Urban Anthropology and Studies of Cultural Systems and World Economic Development $16(3 / 4): 375-404$.

Muecke, Marjorie A. 1987. 'Resettled Refugees' Reconstruction of Identity: Lao in Seattle'. Urban Anthropology and Studies of Cultural Systems and World Economic Development 16 (3/4): 273-289. 
New Zealand Red Cross. n.d. 'Refugee Programmes'. Accessed 13 May 2018 from https://www.redcross.org.nz/what-we-do/in-new-zealand/refugee-programmes/

Patnaik, Soumendra Mohan. 1989. 'Development and Displacement: An Analysis of the Rehabilitation Policies and Programmes of Upper Kolab River Project, Orissa'. Indian Anthropologist 19 (1/2):77-88.

Pitt-Rivers, Julian A. 1954. The People of the Sierra. London: Weidenfeld and Nicolson.

Polanyi, Karl. 1970 [2005]. Primitive, Archaic, and Modern Economies: Essays of Karl Polanyi. Edited by George Dalton. Boston: Beacon Press.

Powell, John Duncan. 1970. 'Peasant Society and Clientelist Politics'. American Political Science Review 64 (2): 411-425.

Richmond, Anthony H. 1993. 'Reactive Migration: Sociological Perspectives on Refugee Movements. Journal of Refugee Studies 6 (1):7-24.

Roniger, Luis. 2012. 'Favors, "Merit Ribbons", and Services: Analyzing the Fragile Resilience of Clientilism'. In Clientelism in Everyday Latin American Politics, edited by Tina Hilgers, 25-40. New York: Palgrave Macmillan.

Sahlins, Marshall. 1965. 'On the Sociology of Primitive Exchange'. In The Relevance of Models for Social Anthropology, edited by Michael Banton, 139-236. New York: Praeger.

Sahlins, Marshall. 1972. Stone Age Economics. New York: De Gruyter.

Schneider, Harold K. 1974. Economic Man: The Anthropology of Economics. New York: The Free Press.

Schneider, Jane, and Peter Schneider. 2001. 'Rethinking Clientelismo: A Challenge from Antimafia Palermo'. In L'anthropologie de la Méditerranée/Anthropology of the Mediterranean, edited by Dionigi Albera, Anton Blok, and Christian Bromberger, 307-329. Paris: Maisonneuve et Larose.

Schrift, Alan D., ed. 1997. The Logic of the Gift: Toward an Ethic of Generosity. New York: Routledge. 
Schwimmer, Erik. 1973. Exchange in the Social Structure of the Orokaiva: Traditional and Emergent Ideologies in the Northern District of Papua. London: C. Hurst \& Co.

Scott, James C. 1972. 'The Erosion of Patron-Client Bonds and Social Change in Rural Southeast Asia. Journal of Asian Studies 32 (1):5-37.

Shore, Cris. 1993. 'Community'. In The Blackwell Dictionary of Twentieth-Century Social Thought, edited by William Outhwaite and Tom Bottomore, 98-99. Oxford: Blackwell Publishers.

Shore, Cris. 2016. 'States of Dependency or Patron-Client Relations? Theorizing Precarity in Academia'. HAU: Journal of Ethnographic Theory 6 (1):127-130.

Silverman, Sydel F. 1965. 'Patronage and Community-Nation Relationships in Central Italy'. Ethnology 4(2):172-189.

Simich, Laura. 2003. 'Negotiating Boundaries of Refugee Resettlement: A Study of Settlement Patterns and Social Support'. Canadian Review of Sociology/ Revue canadienne de sociologie 40 (5):575-591.

Smith, Adam. 1812. The Theory of Moral Sentiments. London: Strahan and Preston.

Stein, Barry N. 1981. 'The Refugee Experience: Defining the Parameters of a Field of Study'. International Migration Review 15 (1/2):320-330.

Stewart, Miriam J. 2014. 'Social Support in Refugee Resettlement'. In Refuge and Resilience: Promoting Resilience and Mental Health Among Resettled Refugees and Forced Migrants, edited by Laura Simich and Lisa Andermann, 91-107. Dordrecht: Springer.

Strathern, Andrew. 1971. The Rope of Moka: Big-Men and Ceremonial Exchange in Mount Hagen, New Guinea. Cambridge: Cambridge University Press.

UNHCR. 2017 (1 July). 'The Sea Route to Europe: The Mediterranean Passage in the Age of Refugees'. Accessed 22 January 2018 from https://www.unhcr. org/protection/operations/5592bdo59/sea-route-europe-mediterraneanpassage-age-refugees.html

Warriner, Doris S. 2007. 'Language Learning and the Politics of Belonging: Sudanese Women Refugees Becoming and Being "American". Anthropology \& 
Education Quarterly 38(4):343-359.

Weissköppel, Cordula. 2013. 'Translocality in Transnational Space: Sudanese Migrants in a Protestant Church in Germany'. Urban Anthropology and Studies of Cultural Systems and World Economic Development 42 (3/4):255-303.

Wolf, Eric R. 1966. 'Kinship, Friendship, and Patron-Client Relations in Complex Societies. In The Social Anthropology of Complex Societies, edited by Michael Banton, 1-22. ASA Monographs Vol. 4. London: Tavistock. 